\title{
積雪密度計（丸型と角型）の良否について
}

\section{Accuracy of Snow-density Gauges}

坂田 初太郎*

H. SAKATA

\section{1. はしがき}

地上気象観貺法によると積雪の比重をはかるには口径 $10 \mathrm{~cm}$ ，梁さ約 $5 \mathrm{~cm}$ の金属製の筒（円形でも角形でもよ い）を用いると記されている。密度計としては丸型でも 角型でも理論上は同一の雪質に対して同一密度が測定さ れるべき筈であるが実際に観測してみるとかなりの密度 差を生ずる。昭和 30 年 1 月ー 3 月迄両型の密度計で毎日 一回 (10時頇) 比較観測を継続した。測器の良否につい ては測器内に雪が自然状態のまま隙間なくつまるかどう かによつて決まる訳である。自然状態のままつまるかど うかの比較検定はこの計量化が甚だ困難ではあるが，測 定を慎重に行兄ば両型共略同程度の誤差範团に入る様に 考えられょう。

測定上大きな誤差を絶えず与えるのは測器のへリに出 来る空除である。これも文計量するのは極めて厄介であ
り，勢いその調査も定性的統計結果に終り勝ちとなる。 雪ひらで雪を切り採る際にも技術が必要で測定值の個人 誤差まで考えると単純な定性的検討には主観が入り易 く，適正を欠く結論に導びく危険が生ずる。この様な次 第で夫々の誤差について夫々計量化す事が大切なのであ るが本交では定量的な結論を出す一補助として理論的統 計処理が出来得るかどうかを概観し，統計理論を借用し てみた。

\section{2. 観測結果}

積雪表面密度観測は毎日 10 時頃昭和 30 年 1 月 4 日 3 月 8 日まで，高田測候所钼測班で実施した。表面雪筫別 にこれを整理すると別表の通りになる。丸型，角型によ る密度差 (丸一角) を $\delta \rho$ とすると $\delta \rho \neq 0$ 且その值も かなり大きい事がある。

角型による密度観測不能になつたのは 1 月16日で雪質 別表 表面雪密度並びに両型湘器による密度差

\begin{tabular}{|c|c|c|c|c|c|c|c|c|c|c|c|c|c|c|}
\hline \multicolumn{3}{|c|}{ 軟いかわきあらゆき } & \multicolumn{3}{|c|}{ 軟いしめりあらゆき } & \multicolumn{3}{|c|}{ 軟いしめりざらめ } & \multicolumn{3}{|c|}{ 軟いぬれざらめ } & \multicolumn{3}{|c|}{ 硬いかわきざらめ } \\
\hline 丸型 & 角型 & $\delta \rho$ & 丸型 & 角型 & $\delta \rho$ & 丸型 & 角型 & $\delta \rho$ & 丸型 & 角型 & $\delta \rho$ & 丸型 & 角型 & $\delta \rho$ \\
\hline 0.21 & 0.19 & 0.02 & $\begin{array}{l}0.17 \\
0.32 \\
\end{array}$ & $\begin{array}{l}0.13 \\
0.27\end{array}$ & $\begin{array}{l}0.04 \\
0.05\end{array}$ & $\begin{array}{l}0.26 \\
0.38 \\
\end{array}$ & $\begin{array}{l}0.24 \\
0.35\end{array}$ & $\begin{array}{l}0.02 \\
0.03\end{array}$ & 0.42 & 0.38 & 0.04 & 0.22 & 0.25 & -0.03 \\
\hline 0.16 & 0.15 & 0.01 & $\begin{array}{l}0.15 \\
0.15\end{array}$ & $\begin{array}{l}0.12 \\
0.15\end{array}$ & $\begin{array}{l}0.03 \\
0.00\end{array}$ & $\begin{array}{l}0.29 \\
0.44\end{array}$ & $\begin{array}{l}0.27 \\
0.43\end{array}$ & $\begin{array}{l}0.02 \\
0.01\end{array}$ & 0.45 & 0.37 & 0.08 & 0.38 & 0.39 & -0.01 \\
\hline $\begin{array}{l}0.14 \\
0.19 \\
\end{array}$ & $\frac{0.15}{0.18}$ & $\begin{array}{r}-0.01 \\
0.01 \\
\end{array}$ & $\begin{array}{l}0.16 \\
0.29 \\
\end{array}$ & $\begin{array}{l}0.16 \\
0.26\end{array}$ & $\begin{array}{l}0.00 \\
0.03 \\
\end{array}$ & $\begin{array}{l}0.48 \\
0.39\end{array}$ & $\begin{array}{r}0.45 \\
0.46 \\
\end{array}$ & $\begin{array}{r}0.03 \\
-0.07 \\
\end{array}$ & 0.36 & 0.33 & 0.03 & 0.45 & 0.42 & 0.03 \\
\hline $\begin{array}{l}0.10 \\
0.12 \\
\end{array}$ & 0.12 & $\begin{array}{c}-0.02 \\
\times \times \\
\end{array}$ & $\begin{array}{l}0.41 \\
0.10\end{array}$ & $\begin{array}{l}0.35 \\
0.11\end{array}$ & $\begin{array}{r}0.06 \\
-0.01 \\
\end{array}$ & $\begin{array}{l}0.39 \\
0.25 \\
\end{array}$ & $\begin{array}{l}0.37 \\
0.17 \\
\end{array}$ & $\begin{array}{l}0.02 \\
0.08 \\
\end{array}$ & 0.38 & 0.42 & -0.04 & & & \\
\hline 0.19 & $\begin{array}{l}0.10 \\
\text { (经傹大) }\end{array}$ & & 0.08 & 0.06 & 0.02 & 0.36 & 0.32 & 0.04 & 0.36 & 0.36 & 0.00 & & & \\
\hline $\begin{array}{l}0.20 \\
0.12\end{array}$ & $\overline{0.23}$ & -0.03 & 0.19 & 0.21 & -0.02 & 0.41 & 0.40 & 0.01 & & & & & & \\
\hline $\begin{array}{l}0.12 \\
0.19\end{array}$ & $\begin{array}{c}0.14 \\
0.13 \\
\text { (空橸大) }\end{array}$ & -0.02 & 0.20 & 0.19 & 0.01 & $\begin{array}{l}0.43 \\
0.48\end{array}$ & $\begin{array}{l}0.40 \\
0.48\end{array}$ & 0.00 & 0.26 & 0.36 & -0.10 & & & \\
\hline $\begin{array}{l}0.17 \\
0.15 \\
\end{array}$ & \begin{tabular}{|l|}
0.15 \\
0.13 \\
\end{tabular} & $\begin{array}{l}0.02 \\
0.02\end{array}$ & & & & $\begin{array}{l}0.49 \\
0.49\end{array}$ & $\begin{array}{l}0.45 \\
0.47\end{array}$ & $\begin{array}{l}0.04 \\
0.02\end{array}$ & 0.41 & 0.42 & -0.01 & & & \\
\hline 0.15 & 0.16 & -0.01 & & & & $\begin{array}{l}0.41 \\
0.37\end{array}$ & $\begin{array}{l}0.37 \\
0.38\end{array}$ & $\begin{array}{r}0.04 \\
-0.01\end{array}$ & 0.37 & 0.38 & -0.01 & & & \\
\hline 0.29 & 0.27 & 0.02 & & & & $\begin{array}{l}0.50 \\
0.44\end{array}$ & $\begin{array}{l}0.54 \\
0.48 \\
\end{array}$ & $\begin{array}{l}-0.04 \\
-0.04\end{array}$ & & & & & & \\
\hline $\begin{array}{l}\text { 平均 } \\
0.17\end{array}$ & 0.16 & & $\begin{array}{l}\text { 平坮 } \\
0.22\end{array}$ & 0.18 & & $\begin{array}{l}\text { 平均 } \\
0.42\end{array}$ & 0.39 & & $\begin{array}{c}\text { 平均 } \\
0.38\end{array}$ & 0.38 & & $\begin{array}{l}\text { 平均 } \\
0.35\end{array}$ & 0.35 & \\
\hline
\end{tabular}

* 高田測候所長 
は軟いかわきあらゆきであつて幾度測定を繰返しても雪 がうまくつまらなかつた。この点, 丸型では廻転し乍ら 雪層中一入れる事が出来るので空陵が出来ることがあつ ても $2 \sim 3$ 回繰返しているうちに大体うまく測定される 事が多い。

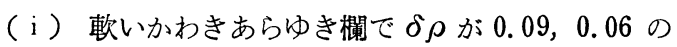
場合は角型測器に空隙がどうしても大きく出た場合で統 計検討する際にはこの值を除外した。他の雪質欄でも解 る様に雪質を一意に定めるには密度だけでは不十分であ り,もつと雪層に対する詳細な観測をして, 雪層の力学 を考慮した要素を見出す必要があるように思われる。 $\delta \rho$ の正負符号の回数は正号 6 回, 負号 5 回, 平均密度

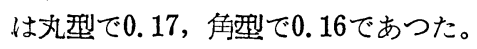

(ii）しめりあらゆき，しめりざらめになると $\delta \rho>0$ の場合が多くなる。角型つ場合は空陣が生じ易いので稍 梁目に雪層中へ沈下させる事があり，このため雪層に圧 力を与え, 圧縮する恐れが多分にある。この様な時に $\delta \rho<0$ が現われる様である。(観測操作中, 時々個人差 がかなり見受けられる）観測結果によると雪層密度が大 きくなるに従い $\delta \rho>0$ の回数が多くなり, $\delta \rho$ の変動 範囲も大きくなる。

(iii）雪質と密度は必ずしも一対一に対応しないが観 測法に基いた雪質に区分して夫々の平均密度を求め図示 したのが図-1 である。ざらめ化まではかわきの次はし めりの順序で急激に密度が増大するがざらめ化するとそ の後の密度増大は急激ではない。ざらめではかわき, ぬ れ, しめりの順序に密度大となつていた。
园-1

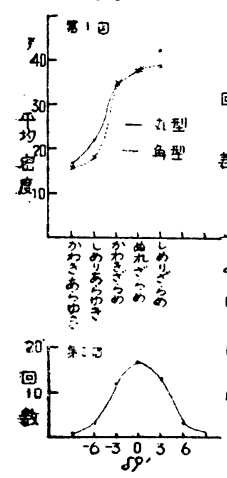

图-3
図-2

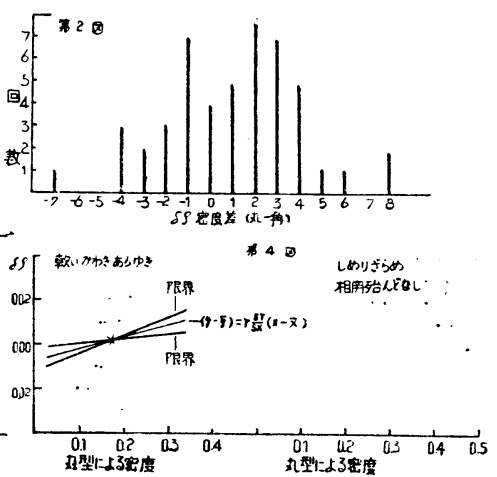

图-4

\section{3. 密度計良否の統計的検討}

両測器には夫々測器自身の特性による誤差と観湘に際 する個人誤差がある。それで個人差を出来るだけなくす る様に雪のとり方を一定にし, 且 2 - 3 回の観測 (勿論 空陌生成が出来るだけなくなる様に慎重に）の平均值を 以つて両测器による密度とすればその差 $\delta \rho$ を統計的に
検討する等でその良否を一応検定し得る筈であらう。

(i ）丸型と㑇型とでは雪質如何によつてその器垩が どの様な分布をしているかを調べてみると $\delta \rho$ の币を 0.01 として観測結果をそのまま図示してみると図一 2 の 様になり，正規分布をしていない。然し $\delta \rho 0$ のを 0.02 にとり，(0.00〜0.02) 間に入るグループを零点 (基点) としてその分布を書き直すと図-3 の様に正規分布型と なつた。この様な变換で正規分布に近似する事を考える と, 観測を慎重にし, 観測技術を向上させると無限母集 団 $\delta \rho の$ 分布は正規の確率分布（円滑な分布曲線）に極 めて近似すると考えても大過はないであろうと思われ る。 $|\delta \rho|=0.02$ の範囲で観測されているのは軟いかわ き雪質だけである。この雪質に対し雪密度に応じて $\delta \rho$ がどの様な相関になつているかを計算してみると, 相関 係数 $r=0.824$ という正の高い相関を示した。この小標 本から丸型による密度に基づいた $\delta \rho$ の母集四の回慢係 数が95\%の信頼限界及び $\delta \rho$ 推定值の標淮偏差を求めて みると第 4 図に示す限界直線が得られた。

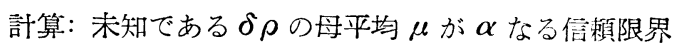
に対して

$$
\begin{aligned}
& P_{r}\left\{-t_{\alpha}<\frac{\overline{\mathrm{X}}-\mu}{S \sqrt{n}}<+t_{\alpha}\right\}=\alpha \text { 方ら } \\
& \mu=\overline{\mathrm{X}} \pm t_{\alpha} \frac{S}{\sqrt{n}}
\end{aligned}
$$

$S$ : 標淮偏差, $n:$ 観測回数, $t_{\alpha}$ はスティーデントの $t$-分布で $\boldsymbol{\alpha}$ が信頼限界,

標本の回帰係数を $\hat{b}$, 母集団の回㷌係数を $b$ とすれば $\frac{(\widehat{b}-b) \sqrt{n-1} S_{x}}{S_{E}}$ は自由度 $(n-2)$ なるステュー デントの $t$-分有をする。

$S_{E}: \delta \rho$ 推定值の標淮誤差

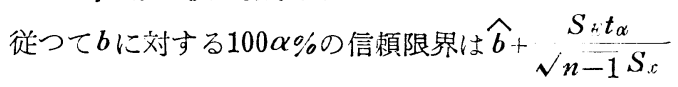
本例では $S_{x}= \pm 0.051, t_{\alpha}=2.262, \alpha=0.95$,

$$
\widehat{b}=0.269, \quad S_{E}= \pm 0.0101
$$$$
\text { となり } b=0.269 \pm 0.14
$$

本例では平均密度 0.17 以上になると $\delta \rho>0,0.17$ 以下になると $\delta \rho<0$ となる傾向が多い等になる。 $0.1 \leq \rho \leq 0.3$ では $\rho=0.1$ で $\delta \rho=-0.005, \rho=0.3$ こ $\delta \rho=0.008$ 以内の变動が標本回㷌直線に追加される程 度である。従つて $S_{E}= \pm 0.0101$ から $95 \% \sigma$ 信頛限界 では最高 $|\delta \rho|=0.018$ で観測され得ると云えよう。

この事から 0.018 以上の $\delta \rho$ が出る場合は更に慎重に 測定を繰返す必要があり, 慎重に測定すれば軟いかわき 雪質では密度計として丸型でも角型でもよいと云えよう し，測定值は小数位 3 枌まで算出すべきであろう。

(ii）（i）歌いかわき雪筫についてのみ検傠したが図 
-4 の傾向分布に従ひ，各雪層を含めた場合の $\delta \rho$ につ いて考穴よう。図一 4 より丸型で測つても，角型で測つ ても真の値との差が粁粋に確率的な変動をすると仮定す る。そうすると $\delta \rho$ も文純粋に確率的变動をする事にな る。そこで雪密度の測定を慎重に実施し同雪質について 3 回観測平均値をもつてこの密度と決定した際, 丸型と 等型とではどの程度の差まで許されるであろうか。言ひ 換えると平均值の理論的標本分布の平均 $\mu \bar{x}$ 並びに標淮 偏羑を $\sigma \bar{x}$ 乞すると 3 個の平均值 $\delta \rho$ は $\mu \bar{x} \pm 3 \sigma \bar{x}$ の間 に $99.87 \%$ 入る事になるがその限界 $3 \sigma \bar{x}$ は幾らであろ 万か。气の推定值は大凡

$$
\beta=3 \sigma \bar{x} \doteq \pm 3 \times 0.341 \times \bar{R}
$$

本試験期間では $R=0.0273$ で $\beta= \pm 0.0279$ となる。 即ち $\delta \rho=0.03$ となると不適当な観測值という等にな る。筧測技術が進めば $R$ も小さくなるので, 更に $\delta \rho$ の許される範囲は小さくなる。従つて問題は測器の型に よつてどの程度の誤差が生じ易いかになつてくる。軟い かわき乩ゆきでは $S_{E}= \pm 0.0101$ であつたから軟いか わき㐫らゆきは丸型, 角型いづれも測器として利用出来
る事が再確認された。所が前節の(2)で述べた様に，しめ りあらゆき，しめりざらめになると $\delta \rho>0$ の回数は多 くなるばかりでなく $\beta の$ 範囲を飛び出す観測が多くなつ てくる。即ちしめりあらゆきでは10回観測中 5 回までが 角型で $\beta$ 以上に小さく出すぎ，丸型にはなかつた。しめ りざらめでは角型が $\beta$ を超えて小さくなるのが 7 回で丸 型では 3 回という事になつている。目視観測上角型測器 に雪がうまくつまらず空鄚を作る事が多い。この事と上 記の理論を使用した結果, 角型密度計は軟いかわきあら ゆき以外の雪質に対しては現業用密度許として不適性が 多いと云えよう。揬術が向上すれば更にしまりあらゆき の測定にも角型が利用出来るかも知れないが同じ雪質で もよくつまるときとつまら娃が起る。ここに雪質の不 思議? があると同時に観測の慎重, 注意さ如何によつて 測定精度を大きく支配するから余程用心をして観測せ㸚 ばならない。

測器の型による空陌生成回数率，雪質等に関して!更 に観测を重妏て報告したい。

\title{
積雪沈降力の增加に関するレオロジー的な考察
}

\section{A Rheolozical Consideration about the Increase of the Settling Force of Snow}

\author{
大浦 浩 交* \\ H. ÔtRA
}

\section{1. まえおき}

積雪沈降力は, 吉田・平田による報告以来多くの人達 が測定或は観察を続けているり。こっではその沈降力増 加に関する極端な 2 つ型について注意をむける。その 2 つの型の 1 つは, 積雪量が徐々に増加し, したがつて 沈降力も積雪量の增加分に比例して増加する場合で, 他 の 1 つ泣, 降雪が一時に大量にあつても, 沈降力はそれ ほど增加しないが，その後，降雪は無くても沈降力はず んずん増加して，前の場合（同量の雪夯徐々に降つた場 合）と同じ程度にまで増大する場合とである。

この事を加重圈説によつて説明するとすれば徐々に雪 が降つた場合には加重圈の広さ（布団の巾）は降雪によ つて変らないが，急激に大量の雪が降つた場合には，降 りたてには加重圈の広さが狄いが，其後日が経過すると 広くなつて, 徐乃に降つた場合と等しくなるとゆうこと
になる。

こ〉では加重圈の増減には深く立入らないで,たぐこ の $2 つ の$ 型は積雪が粘弾性的な性質を持つておれば当然 起ることである々ゅうことを準定量的に説明しょうと 思う。

佮そのほかに，上の説明のために用いた手統と同様な 手続によつて説明できる 2,3 の場合について述べる。

\section{2. 沈降力増加の観測}

1954年12月末から1955年 3 月末にかけて札幌の北海道 大学構内に於て, 地上高 $30 \mathrm{~cm}, 60 \mathrm{~cm}$ の水平桁にか 〉る 積雪沈降力を測定した。この沈降力と，12月21日（根雪 の初日）から，その沈降力を測定した時までの降水量の 積算値との関係を示したのが図ー1 である。

積算降水量に対する沈降力增加の割合 $(\mathrm{kg} / \mathrm{m} \cdot \mathrm{mm})$ は次表によつて示される。

* 低温科学研究所 